\title{
The relationship between teacher efficacy and attitude towards inclusive education in private elementary school: A study based on teaching experiences
}

\author{
Tiza Meidrina ${ }^{1 *}$, Sulfani Nur Mawaddah ${ }^{2}$, Frieda Maryam Mangunsong Siahaan ${ }^{3}$ \\ Pratiwi Widyasari 4
}

1, 2, 3, 4 Psikologi, Fakultas Psikologi, Universitas Indonesia, Depok, Indonesia

\section{Key Words \\ Teacher efficacy \\ Teacher attitude \\ Inclusive education \\ Private elementary school}

Received: 3 November 2016

Accepted: 17 March 2017

Published: 30 June

\begin{abstract}
This study is aimed to analyze the relationship between teacher ef6icacy and teacher attitude toward inclusive education reviewed by teaching experiences in private elementary schools in Jakarta and Depok. Ninety-seven private elementary teachers are involved in this research. This quantitative study uses the Teacher's Sense of EfBicacy Scale (TSES) to measure teacher efficacy and the Multidimensional Attitudes Towards Inclusive Education Scale (MATIES) to measure teachers' attitudes. The result reveals that there is a significant positive correlation between teacher efBicacy and teacher attitude towards inclusive education $(\mathrm{r}(97)=321, \mathrm{p}<.01)$. It shows that when the teachers have high efficacy about their competence, their attitude towards inclusive education increases. On the other side, the relationship between two variables, when reviewed by teaching experiences, varies. This study also shows there is no differences in teacher ef6icacy $(F(94)=.212, p>.05)$ and teacher attitude $(F(94)=.335, p>.05)$ for the teacher with different teaching experiences. This study reveals that teacher with different teaching experiences have the same belief about their competence as a teacher and have the same attitude toward inclusive education.
\end{abstract}

(C)2017 The Author9(s). Published by TAF Publishing

\section{INTRODUCTION}

In the last few decades, it is very often to heard about inclusive education in Indonesia. This term becomes common for Indonesian citizens, especially since the beginning of new millenium. In Indonesia itself, the government make serious efforts to develop inclusive education system through the development of inclusive schools in many areas in Indonesia. From, Dinas Pendidikan Kota Depok (2014), it was been said that the government of Indonesia make attempts to increase the number of inclusive schools in Indonesia since 2009. Basically, Inclusive Education can be describe as a processess to integrate the individuals with disability in regular school. The purpose of this attempt is to create the least restirctive environment. This thing is written in United States of America right 94-142 1975 (Scruggs and Mastropieri, 1996).

Generally, the development of inclusive education system is appropriate according to the purpose of education itself, that is to develop every child potential comprehensively in every aspect like behaviour, knowledge and social skill (Katz and Pat, 2002; Owusu, 2016; Nuchso et al., 2016). The purpose of education is not only aimed to the reguler children

\footnotetext{
${ }^{*}$ Corresponding author: Tiza Meidrina

†Email: tmeidrina@gmail.com
} 
but also for the children with disabilities.

Accordance with the law of Indonesian Government No. 20 tahun 2003 which explained that education is the rights for every children, with no exception (Sisdiknas, 2016). In indonesia, inclusive school have been implemented since 2003 as noted in $2003 \mathrm{In}$ donesian Law of National education system (Sunardi et al., 2014). Ever since, the inclusive school have been developed in many province in Indonesia. Moreover, one of the province in Indonesia, that is West Java is already declared as inclusiive education province (Dinas Pendidikan Kota Depok, 2013).

As a new system for education in Indonesia, surely the implementation of inclusive education is not easy. There are several challenges in to implement this system. The challenges can come from the community, the structure of the school and human resources in schools. The challenges are occured due to the restructuring of the schools that were originally including regular category and turned into inclusive system. One of the challenges in the inclusive education is come from the teachers. It is undeniable that the changes of school system will also affect the responsibility of the teachers in the classroom. Based on the research done by Scruggs and Mastropieri (1996), the regular school which changes into inclusive schools are not always followed by a positive attitude of the teacher. Bahar (2004), added that the attitude of the teachers who do not tend to support the inclusive education is also occured because of the more complex responsibilities to educate the regular students and also the students with disabilities.

The success of inclusive education could not be removed from the role of teachers in supporting inclusive education. As individuals who interact directly with the students, surely the role of teachers are considered very important in the development of the students. One of the things from the teacher who also influenced the success of inclusive education which is the attitude of teachers toward inclusive education (Kurniawati et al., 2012). The attitude of teachers toward inclusive education is seen very important in the success of inclusive education. It is the teachers attitude will affect the academic achievement and social participation both in regular student and special student. In addition, a positive attitude will make the teachers more prepared in accommodating the needs of students.

There are several factors that affect the teachers attitude toward inclusive education including demographic factors such as teaching experience, gender, age, contact with person with disabilities and the severity of the children (Scruggs and Mastropieri 1996), the responsibility in the classroom (Bahar, 2004), training and self efficacy (Vaz et al., 2015). From various factors above, there is a factor that come from within the teachers which are considered have an important influence related to the teachers attitude, that is teacher efficacy. Tschannen-Moran et al. (1998), defines that the teacher efficacy can be defined as a belief in teachers self about their ability to organise and take actions that are useful to reach the teachers task in certain contexts. Tschannen-Moran et al. (1998) also added that the teacher efficacy is a form of self efficacy that related to teachers.

According to Ross et al. (1996) there are several factors that affect teacher efficacy. Those factors including feelings of being well-prepared, Student engagement, levels of education (Ross et al., 1996), teaching experiences (Tschannen-Moran et al., 1998) and gender (Lee et al., 1991; Ross et al., 1996).

Some of the previous research shows that teacher efficacy will affect how teachers implement a variety of teaching strategies and attitudes toward inclusive education Chester and Beaudin (as cited in Vaz et al., 2015). It is also supported by the research done by Palmer (as cited in Forlin et al., 2009) which stated that the teachers behaviour in the 
classroom will be influenced by the efficacy on themself. This situation will have an impact on how teachers see the effectiveness of teaching activities that they did in the classroom. Then, it can be understood that when teachers have a high efficacy it will also have an impact on the achievement of the students in the classroom.

From the variables teacher efficacy or the attitude of teachers toward inclusive education, it founds there is a factor that can affect both variables. The factor is the teaching experience. Researchers saw that teaching experience will affect the relationship between teacher efficacy and attitudes toward inclusive education. Furthermore, teaching experiences will also have an impact on the success of inclusive education. According to Forlin (as cited in Shaukat et al., 2013) teaching experience will affect the positive attitude of teachers toward inclusive education. However, different results found in the research done by Clough and Geoff (1991). From the results of this study thus ind that teachers with the more teaching experience have a more positive attitude toward inclusive education. In addition, Tschannen-Moran et al. (1998) indicates that the teachers who have experiences under three years have a lower score in teacher efficacy than the teachers who have taught above four years.

Based on the explanations of the influence of teaching experiences, Huberman (1989) divide teaching experiences into five category. First, the 1-3 irst year. At this stage teachers undergoing a process of survival and discovery. Continue with the stage of stabilization, on 4-6 years teaching. At this stage, teachers start to committ with their work. The next stage is the mid-career stage between 7-18 years. This stage is marked with reassessment of their career options. The next phase is serenity that occurs on 19-30 years long taught. At this stage, teachers will experience a drop in energy and enthusiasm. The inal stage is disengagment on the period of 31-40 years long taught. At this stage the teachers will assess how his work during the period of his life.

Basically, the role of the teacher is very essential in the development of a child in every level of education. But it is undeniable that the experience in the primary school is very important in determining the success of the children in the future (Papalia and Ruth, 2012). In addition, based on psychosocial developmental stage, Erikson (Papalia and Ruth, 2012), sad that the children in primary school is developing the virtue competence. This explains that children are developing competency feelings in themselves to face the social life. Therefore, the role of the teacher is very important in developing that virtue.

In Indonesia, there are various types of schools from the elementary kindergartens to highschool. Based on its management, schools can be divided into two types namely, the public school and private schools are. Based on Choy (1997) shows that private schools teachers feel much more satisfied with the condition of their work compared with teachers in schools. It is also supported with greater benefits in terms of salary and insurance obtained by the teachers in private schools. On the other research that is done by Lee et al. (1991), shows that the organization of the school will affect how teachers see their work and the way they taught. Indirectly, this also will affect the learning process for the students. The organization of the school can be seen based on the management of the private schools. School organization that is able to facilitate the teacher in arranging the classroom environment and embrace their needs will affect the perception of the teachers in their work. In the context of the inclusive private school, Kurniawati, et al. (2012) find the results that teachers at the private inclusive school has more positive attitude toward inclusive education. 


\section{LITERATURE REVIEW}

In defining the attitude, there are many social psychologist which seeks to explain the meaning of attitude. De Boer, (2012) explained that the attitude is the point of view of someone who also involves a specific response in cognitive, affective and conative. The definition of other attitude according to Fishbein and Icek $(1975,6)$ is a tendency how a person responsd favorable or unfavorable to the object of the attitude. While according to Sarwono and Eko, (2009), the attitude is defined as a evaluative reaction is preferred or not preferred and shows the belief, feelings or the tendency of behavior.

From the various explanations, it can be concluded that the attitude is the tendency of a person to respond to the object of attitude in terms of cognitive, affective or conative. Although the attitude is something that there is on the individual and cannot be observed directly but the attitude can be seen from the knowledge or the feelings an how a person take an actions over the object of attitude. In this research, the attitude can be understood as a teacher respond towards the implementation of inclusive education in terms of physical, social and curriculum.

When discussing the definition of the teacher efficacy, cannot be removed from the sense of self-efficacy by Bandura (1997) as the person who proposed this term for the first time. Feist et al. (2013) self efficacy can be defined as a someones belief on their ability to do something. The someones belief is reflect the cognitive factors of the person. Tschannen-Moran et al. (1998) remarked that teacher efficacy is a form of self efficacy. Teacher efficacy itself can be defined as a belief in teachers about their ability to organise and take actions that are useful to reach the task as teachers in certain contexts. There are three dimensions of teacher efficacy. The dimension of the efficacy in student engagement, efficacy in instructional strategies and efficacy in classroom management. There are several factors that affect both the attitude and teacher efficacy including training, gender training and experience teaching teachers. In this research will be seen the relationship between teacher efficacy with the attitude of the teachers reviewed from experience teaching teachers. Various studies show that teaching experience teachers have different influence on the attitude of teachers and teacher efficacy. In this research, experience teaching teachers is divided based on the class teachers life cycle as suggested by Huberman (1989). The first phase of the novice teacher. This stage occurs on 1-3 first year a teacher. At this stage one just choose the work as a teacher for his career. At this time the teachers experiencing the situation has not been general, feelings of doubt and enthusiasm. On the other hand it also consider whether its social environment saw himself as a competent teachers. The second stage, middle novice stage that occurs on 4-6 years long taught. At this stage, a teacher has a commitment to his work. The teachers will be working hard on this stage and have a great responsibility. Next is the mid-career class teachers on 7-18 years long taught. At this stage the teacher is considered professional in kind. The teachers will be easy to apply the previous experiences to resolve the other problems it encounters. But at this stage also teachers start to feel bored with his work and to leave-minded his work. In addition, at this stage the teachers also have the framework of thinking that remains and sometimes difficult to receive new ideas.

The next phase is the last career stage that occurs on 19-30 years long taught. At this stage, a teacher is able to control various conditions class and can relate his work with his social situation. In addition, at this stage of the teachers have already started to give the distance himself with his work. The inal stage of the namely, career satisfaction stage that occurs on a range of 31-40 years long experience teaching. At this stage, teachers will see and reflect the experience that they have.

From the explanation above, the researchers are interested to do a research to analyze 
the relationship between teacher efficacy and attitude toward inclusive education that reviewed by teaching experiences. The hypothesis that the writer ask in this research are:

1: There is a significant relationship between teacher efficacy and attitudes toward inclusive education in teachers at private inclusive elementary school.

2: There is a significant relationship between teacher efficacy and attitudes toward inclusive education in teachers at private inclusive elementary school who have teaching experience in a range of 1-3 years.

3: There is a significant relationship between teacher efficacy and attitudes toward inclusive education in teachers at private inclusive elementary school who have teaching experience in a range of 4-6 years.

4: There is a significant relationship between teacher efficacy and attitudes of teachers toward inclusive education in teachers at private inclusive elementary school who have teaching experience in a range 7-18 years.

5: There is a significant relationship between teacher efficacy and attitudes of teachers toward inclusive education in teachers at private inclusive elementary school who have teaching experience in a range 19-30 years.

6: There is a significant relationship between teacher efficacy and attitudes of teachers toward inclusive education in teachers at private inclusive elementary school who have teaching experience in a range of 31-40 years.

7: There is a significant difference in teacher efficacy between teachers who have experience teaching in a different range of teaching experiences.

8. There is a significant difference in the attitude toward inclusive education between teachers who have different teaching experiences.

RESEARCH METHOD

This research involving 97 teachers who become respondents from private inclusive schools in Jakarta and Depok. Characteristics of the samples in this research are inclusive primary school, teaching experience a minimum of one year and is a class teachers or subject teachers. Sampling techniques in this research is convenience sample, which is how the sampling based on the availability and willingness of the participant. On this research, researchers use the measuring cup Class Teachers' Sense of Efficacy and multi-dimensional measure attitudes toward inclusive educational school (MATIES-IV) to measure the attitude of teachers. While the measurement experience teaching seen from the demographic data that is filled by the participant in kusioner sheet.

\section{RESEARCH RESULTS}

In this section will be explained about the results of this research:

- The results from the total score teacher efficacy and attitudes toward inclusive education in general will be described in the Table 1 follows:

TABLE 1. Relationship between teacher efficacy and the attitude of the teachers in general

\begin{tabular}{lllllll}
\hline \hline & The Variables & Mean & $S D$ & 1 & 2 & $R 2$ \\
\hline 1. & Teacher Efficacy & 102.84 & 6.182 & 1 & $.321^{* *}$ & .103 \\
2. & The Attitude of Teachers & 84.88 & 8.33 & $.321^{* *}$ & 1 & .103 \\
\hline \hline Note: ${ }^{* *} P<.01,{ }^{*} p<.05$
\end{tabular}

Based on the table above shows that there is a positive and significant relationship between teacher efficacy and attitudes of teachers toward inclusive education $(r(46)=.576$, $p<.01$ ) on the teachers who have taught for 1-3 years. From this result and means the 
number two alternative hypothesis accepted. The results of this correlation, shows that the higher the teacher efficacy will be followed with positive attitude toward inclusive education in the teachers who have experience teaching in a range of 1-3 years.

- The relationship between Teacher efficacy with the attitude of Teachers toward inclusive education on teachers with experience teaching 4-6 years. Based on data collected in this research participants included in the group of experience teaching 4-6 years as many as 19 participants. According to the Guilford and Benjamin (1981), when samples research participant less than 30 , then the distribution will not spread normal. It will affect the research results so that the result is not considered valid and is not able to describe the population. Therefore, on the group of 4-6 years of teaching experiences, the calculation of the correlation cannot be done.

- Though results data from the total score teacher efficacy and attitudes of teachers toward inclusive education on teachers with experience teaching 7-18 years, will be described in the Table 2 follows:

TABLE 2 . Components of the teacher efficacy and attitude of the teachers with experience teaching 7-18 years

\begin{tabular}{cllllll}
\hline \hline & The Variables & Mean & $S D$ & 1 & 2 & $R 2$ \\
\hline 1 & Teacher Efficacy & 103.41 & 5.59 & 1 & -.072 & .52 \\
2 & The Attitude of Teachers & 84.16 & 6.77 & -.072 & 1 & .52 \\
\hline \hline Note: ${ }^{* *} P<.01,{ }^{*} p<.05$ & & & &
\end{tabular}

Based on the table above shows that there is no relationship between teacher efficacy and attitudes of teachers toward inclusive education $(r(32)=-.072, p>.05)$ on teachers who have experience teaching during 7-18 years. Based on the results of the alternative hypothesis the number four rejected.

- The relationship between Teacher efficacy with the attitude of Teachers toward inclusive education on teachers with experience teaching 19-30 years and 31-40 years. Based on the data obtained in this research, no participant research that is in a range of group experience teaching 19-30 years and 31-40 years. That makes two groups experience teaching, cannot be explained the results though data on research.

- Comparison of Teacher efficacy based on teaching experience.

TABLE 3 . Comparison of teacher efficacy based on teaching experience

\begin{tabular}{llll}
\hline \hline $\begin{array}{l}\text { The Experience of } \\
1-3 \text { Years }\end{array}$ & $\begin{array}{l}\text { The Experience of } \\
\text { 4-6 Years }\end{array}$ & $\begin{array}{l}\text { 7-18 Years Experi- } \\
\text { ence }\end{array}$ & $F$ \\
\hline$M(S D)$ & $M(S D)$ & $M(S D)$ & $\begin{array}{l}F(2.94)=.212, p> \\
0.05\end{array}$ \\
& & $103.41(5.599)$ & \\
$102.63(6.793)$ & $102.37(5.795)$ & & \\
\hline
\end{tabular}

Based on the results of the process of data shows that there is no difference in the teacher efficacy between teachers with teaching experience between 1-3 years, 4-6 years and 7-18 years. From the data shows that the number of alternative hypothesis five rejected.

- Comparison of the attitudes of Teachers toward inclusive education based on teaching experience.

From the results if the data shows that there is no difference in the attitudes of teachers toward inclusive education between teachers with teaching experience between 1-3 years, 
TABLE 4. Comparison of teacher efficacy based on teaching experience

\begin{tabular}{llll}
\hline \hline $\begin{array}{l}\text { The Experience of } \\
\text { 1-3 Years }\end{array}$ & $\begin{array}{l}\text { The Experience of } \\
\text { 4-6 Years }\end{array}$ & $\begin{array}{l}\text { 7-18 Years Experi- } \\
\text { ence }\end{array}$ & $F$ \\
\hline$M(S D)$ & $M(S D)$ & $M(S D)$ & $\begin{array}{l}F(2.94) .335, p> \\
0.05\end{array}$ \\
& & & \\
$85.61(8.048)$ & $84.32(11,275.4)$ & $84.16(6.778)$ & \\
\hline \hline
\end{tabular}

4-6 years and 7-18 years. Though based on the results of the data on the table, shows that the number of alternative hypothesis six rejected.

\section{DISCUSSION}

1. In general, this research shows that there is a significant positive relationship between teacher efficacy with the attitude toward inclusive education on teachers who become research participants. From this result explains that the higher teacher efficacy will be followed with positive attitude toward incluasive education.

This results in accordance with the previous research conducted by Vaz et al. (2015) which shows that there is a relationship between self efficacy with the attitude of teachers toward inclusive education. Other research conducted by Jordan et al.(1993) shows that when teachers have high self efficacy and will also affect the willingness of teachers in finding the needs of the students of the students. The willingness of teachers in finding the needs of the students are of course will affect how teachers respond to the way the educational process in the classroom and the implementation of inclusive education itself.

From the results of a correlation between the dimensions of teacher efficacy with total the attitude of teachers toward inclusive education, also found significant relationships on every dimension. But the most significant relationships can be found on the correlation between the dimensions of classroom management with total score the attitude toward inclusive education.

2. Based on the results of research and found a significant positive relationship between teacher efficacy with the attitude toward inclusive education on teachers with experience teaching 1-3 years. This result can be explained by the data processing is done by the researchers showed that 33.1 percent variance from the attitude of the teachers can be explained by the teacher efficacy. This result is also explained that the teacher efficacy has a strong relationship to explain the formation of the attitude. Other factors that also explains the formation of the attitude can be seen from the factors such as, gender, contact with CREW, training, age and levels of education.

It is undeniable that the characteristics of teachers who teach on a range of 1-3 years can also affect the good teacher efficacy and the attitude of teachers toward inclusive education. As explained by Huberman (1989), the range of teaching 1-3 years a teacher experienced distractions as well as a sense of enthusiasm in a new job. This can also be another factor that influenced the results of the correlation between teacher efficacy and attitudes of teachers toward inclusive education. Another thing that also affect the result is that the number of participants. From the total amount of participants, there are 46 participants that are within the range of experience 1-3 years. The number of considered representative in describing the population. This can also affect the significance of the results on the correlation between teacher efficacy with the attitude of teachers toward inclusive education on a range of Group 1 to 3 years experience. 
3. In the group of participants with teaching experiences 4-6 years the number of participants that have collected does not reach 30 participants. That makes the calculation of the statistics cannot be done so that could not be seen the relationship between teacher efficacy with the attitude of the teachers in the group of 4-6 years teaching experiences.

4. The results of the study showed that there is no relationship between Teacher efficacy and the attitude towards inclusive education on teachers with teaching experiences 7-18 years. Researchers suspect is not the discovery of the relationship between teacher efficacy with the attitude can be due to other factors that more related to the attitude of the teachers. As described in the research Vaz et al. (2015), The Age Factor, gender, contact with the crew and training is a factor that also influenced the attitudes of teachers toward inclusive education. Research in the Vaz et al. (2015), results found that age, gender, contact with the crew and training can explain 42 percent variance from the attitude of teachers toward inclusive education. While from the results of research done researchers, teacher efficacy only able to explain the 5.2 percent variance from the attitude of teachers on a range of teaching experience 7-18 years.

The characteristics of teachers who teach on a range of 7-18 years can also be other factors that influenced the results of this research. As explained by Huberman (1989), the range of 7-18 teaching experiences have been able to apply the experience and know how to solve the problem in schools. In addition, on this stage teachers are often minded to leave his work and have fix mindset.

5. The results of the study showed that there was no difference in the teacher efficacy between the teachers with teaching experiences 1-3 years, 4-6 years and 7-18 years. This result is different with the results of research done by Tschannen-Moran et al. (1998), which shows that the teachers with teaching experiences under three years have lower teacher efficacy than with the teachers who have taught above four years. The results from this research is also accordance with the previous research conducted by Klassen and Ming (2010), find that teacher efficacy has a relationship which is not linear with teaching experience. It described that teacher efficacy will increased in the range of 0-23 years of experiences, and decreased afterwards. The different between previous research with this research can be due to the sample which is not representative enough to describing the population.

6. From the results of the study showed that there were no differences in the attitudes of teachers toward inclusive education between the teachers with experience 1-3 years, 4-6 years and 7-18 years. These findings support the research done by Jnr (2010), that teaching experiences does not affect the attitude of teachers toward inclusive education. But different from the findings from Leyser et al. (1994), that teachers with less experiences and above 11 years of experiences has a more positive attitude toward inclusive education. Factors that can affect the results of these findings can be due to the number of participants who are not representative in each experience group to represent the population.

\section{CONCLUSION}

Based on the results of the process data to answer the research problem and prove the hypothesis research, then on this section will be described the conclusion from the results of research. From the results if the data showed that the there is a significant and positive relationship between teacher efficacy with the attitude toward inclusive education. The result was also proved that the first alternative hypothesis accepted. In addition, from the dimension of the teacher efficacy with total score teacher attitude also shows that there is a significant positive. Though results data row shows there is a significant positive rela- 
tionship between teacher efficacy with the attitude toward inclusive education on teachers with teaching experiences of 1-3 years. From the results of the second alternative hypothesis accepted.

Though results data also shows that there is a significant positive relationship between each dimension of the teacher efficacy with total score the attitude in the group experience 1-3 years.

In the group of experience 7-18 years there is no significant relationships between teacher efficacy with the attitude towards inclusive education. The result shows that the number of alternative hypothesis four was rejected. Based on the participant collected in the research, there is no participant in the group with a range of teaching experiences 1930 years and 31-40 years. This makes the calculation of these two groups cannot be done. Though results data shows that there is no difference between teacher efficacy on teachers with teaching experience between 1-3 years, 4-6 years and 7-18 years. From the results of the hypothesis number seven rejected. Accordance with the result, found that there is no difference between the attitude of the teachers with teaching experiences between 1-3 years, 4-6 years, and 7-18 years. This result also explains that the number of hypothesis eight is rejected.

\section{LIMITATIONS AND RECOMMENDATIONS}

This study has some limitations. Researchers are not able to do the calculation in the participants group of 4-6 teaching experiences. This is due to the number of participants who do not meet the minimum requirement participant. Participants in the range of experience 4-6 years are only 19 participants, while according to Guilford and Benjamin (1981), the minimum number of samples of the participants as many as 30 . When the number of samples less than 30 , then the data will not spread normal and will affect the results of research. Thus, this research must be replicated in future.

There are some suggestions that the researchers discussed possible for the next researcher who will take the same topic, including: doing in-depth interviews and also make observations related to how teachers fill the questionnaire. This is very useful for researchers to knowing and capture nonverbal communication which indicates that maybe some teachers do not understand the specific items. In addition, the next researchers, who want to see both variables based on teaching experience, have to make the numbers of participant balance in every teaching experiences group. Especially on the teaching experiences in the range of 4-6 years where the number of participants is not representative. Another advice are the difference between the characteristics of teachers in each range of teaching experience can become a consideration for the school in evaluating teacher performance or provide specific training for teachers in accordance with the amount of experiences they have. In addition, this research can also become a consideration for the school to develop teacher efficacy through training, counseling, and also create a conducive climate in schools. The results of this research is also expected to be able to become a consideration for the school or the related party to develop teacher efficacy and positive attitude toward inclusive education. That development can be done in various ways such as seminars or training. Moreover, this research is expected to provide benefits for the implementation of inclusive education in Indonesia. It is expected that school and the government can collaborate together to improve the quality of inclusive education in Indonesia.

\section{REFERENCES}

Bahar, Cheryl. 2004. The relationship between teacher efficacy and inclusion: An analysis of general and special educator perspectives. Ph.D. dissertation, University of California, Los Angeles, CA. 
Bandura, Albert. 1997. Self-efficacy: The exercise of control. New Yo rk, NY: W. H. Freeman.

Choy, Susan P. 1997. Public and private schools: How do they differ?. New Jersey, NJ: National Center for Education Statistics.

Clough, Peter, and Geoff Lindsay. 1991. Integration and the support service. National Foundation for Educational Research (NFER), Slough, UK.

De Boer, Anke A. 2012. Inclusion: A question of attitudes? A study on those directly involved in the primary education of students with special educational needs and their social participation. Doctoral dissertation, University of Groningen, Groningen, NL.

Dinas Pendidikan Kota Depok. 2013. Jawa barat deklarasi provinsi pendidikan inklusif.

URL: http://disdik.depok.go.id/?p=298 (accessed December 27, 2016).

Dinas Pendidikan Kota Depok. 2014. Pendidikan inklusi lemah di Guru. URL: URL: http://disdik.depok.go.id/?p=298 (accessed December 3, 2015).

Feist, Jess, Gregory J. Feist, and Tomi-Ann Roberts. 2013. Theories of personality. 8th ed. New York, NY: McGraw-Hill. Fishbein, Martin, and Icek Ajzen. 1975. Belief, attitude, intention, and behaviour: An introduction to theory and research. Massachusetts, MA: Addison-Wesley.

Forlin, Chris, Tim Loreman, Umesh Sharma, and Chris Earle. 2009. Demographic differences in changing pre-service teachers' attitudes, sentiments and concerns about inclusive education. International Journal of Inclusive Education 13, no. 2: 195-209. DOI: 10.1080/13603110701365356

Guilford, Joy P., and Benjamin Fruchter. 1981. Fundamental statistic in psychology and education. New York, NY: McGraw-Hill.

Huberman, Michael. 1989. The professional life cycle of teachers. Teachers College Record 91: 31-57.

Jnr, Francis R. 2010. Teacher characteristics as predictor of attitude towards inclusive education in the cape coast metropolis of Ghana. IFE PsychologIA : An International Journal 18, no. 2: 35-47.

Jordan, Anne, Gonul Kircaali-Iftar, and CT Patrick Diamond. 1993. Who has a problem, the student or the teacher? Differences in teachers' beliefs about their work with at-risk and integrated exceptional students. International Journal of Disability, Development and Education 40, no. 1: 45-62. D0I: 10.1080/0156655930400104

Katz, Jennifer, and Pat Mirenda. 2002. Including students with developmental disabilities in general education classrooms: Social benefits. International Journal of Special Education 17, no. 2: pp. 26-36.

Klassen, Robert M., and Ming Ming C. 2010. Effects on teachers' self-efficacy and job satisfaction: Teacher gender, years of experience, and job stress. Journal of Educational Psychology 102, no. 3: 741-756. D0I: 10.1037/a0019237

Kurniawati, Farida, Alexander Minnaert, Frieda Mangunsong, and Wondimu Ahmed. 2012. Empirical study on primary school teachers' attitude towards inclusive education in Jakarta, Indonesia. Procedia-Social an Behavioral Sciences 69: 1430-1436. DOI: 10.1016/j.sbspro.2012.12.082

Lee, Valerie E., Robert F. Dedrick, and Julia B. Smith. 1991. The effect of the social organization of schools on teachers' efficacy and satisfaction. Sociology of Education 64, no. 3: 190-208. DOI: 10.2307/2112851

Leyser, Yona, Gaylen Kapperman, and Robert Keller. 1994. Teacher attitudes toward mainstreaming: A cross-cultural study in six nations. European Journal of Special Needs Education 9, no. 1: 1-15. D0I: 10.1080/0885625940090101

Owusu, Nicodemus 0. 2016. Collaborative knowledge management: Examining the challenges in the rural banking industry in the eastern region of Ghana. International Journal of Humanities, Arts and Social Sciences 2, no. 3: 111-120.

Papalia, Diane E., and Ruth Duskin F. 2012. Experience human development. New York, NY: McGraw-Hill.

Ross, John A., Bradley Cousins J., and Tahany Gadalla. 1996. Within-teacher predictors of teacher efficacy. Teaching and Teacher Education 12, no. 4: 385-400. D0I: 10.1016/0742-051X(95)00046-M

Sarwono, Sarlito W. , and Eko A. Meinarno. 2009. Psikologi sosial. Jakarta, ID: Salemba Humanika.

Scruggs, Thomas E., and Mastropieri, Margo A. 1996. Teacher perceptions of mainstreaming/inclusion, 1958-1995: A research synthesis. Exceptional Children 63, no. 1: 59-74. DOI: 10.1177/001440299606300106

Shaukat, Sadia, Umesh Sharma, and Brett Furlonger. 2013. Pakistani and australian pre-service teachers' attitudes and self-efficacy towards inclusive education. Journal of Behavioural Sciences 23, no. 2: 1-16. 
Sisdiknas. 2016. Undang-undang Republik Indonesia Nomor 20 Tahun 2003 tentang Sistem Pendidikan Nasional. URL: https://kemenag.go.id/ (Accessed on Feburary 11, 2016).

Sunardi, Sunardi, Maryadi Maryadi, and Sugini Sugini. 2014. The effectiveness of a two-day inclusion workshop on teachers' attitudes, understanding, and competence in inclusive education. World Journal of Education 4, no. 5: 77-85. DOI: $10.5430 /$ wje.v4n5p77

Tschannen-Moran, Megan, Anita Woolfolk H., and Wayne K. Hoy. 1998. Teacher efficacy: Its meaning and measure. Review of Educational Research 68, no. 2: 202-248. DOI: 10.3102/00346543068002202

Vaz, Sharmila, Nathan Wilson, Marita Falkmer, Angela Sim, Melissa Scott, Reinie Cordier, and Torbjörn Falkmer. 2015. Factors associated with primary school teachers' attitudes towards the inclusion of students with disabilities. PloS one, 1-12. DOI: 10.1371/journal.pone.0137002

— This article does not have any appendix. — 